\title{
ROLA SWIECKICH W PISMACH OJCÓW APOSTOLSKICH I APOLOGETÓW GRECKICH II WIEKU
}

Próbę określenia roli, jaką pisma tzw. Ojców Apostolskich i Apologetów greckich II wieku nadawali osobom świeckim w Kościele antycznym warto rozpocząć od przypomnienia pewnych oczywistych założeń ogólnych. Po pierwsze więc, opis roli świeckich w Kościele I i II wieku w interesujących nas tekstach uzależniony jest w dużej mierze od pism Nowego Testamentu, zwłaszcza Listów apostolskich. Po drugie, analiza istniejących świadectw powinna koncentrować się zarówno na aspekcie filologicznym, jak również merytorycznym. Oznacza to, że przedmiotem badań powinny stać się zarówno fragmenty tekstów, w których występuje termin ,świecki”, ale również takich, w których on się nie pojawia się, a rola świeckich w konkretnych wspólnotach chrześcijańskich opisana została za pomocą innej terminologii. Sam bowiem brak specyficznej terminologii może być mylący i jeszcze o niczym nie świadczy. Otóż, termin $\lambda$ aïxós zasadniczo nie występuje w pismach tego okresu $\mathrm{z}$ wyjątkiem 1 Listu do Koryntian $(40,5)$ Klemensa Rzymskiego, gdzie pojawia się on po raz pierwszy. Byłoby jednak błędem sądzić tylko na takiej podstawie, że świeccy nie odgrywali żadnej konkretnej roli w Kościele pierwotnym. Oznacza to jedynie, iż skazani jesteśmy na świadectwa pośrednie, tzn. na te teksty, w których choć sam termin nie występuje, to jednak pojawia się, choć inaczej opisana, właśnie sama rzeczywistość udziału świeckich w życiu Kościoła antycznego. Nie możemy tych świadectw absolutnie lekceważyć pamiętając oczywiście ciągle o trudnościach związanych $z$ ich interpretacją. $\mathrm{Z}$ jednej bowiem strony wyrażają one niewątpliwie samoświadomość pierwszych wspólnot chrześcijańskich na temat roli w nich świeckich, innym zaś razem opisują jedynie funkcje faktycznie przez nich sprawowane bez glębszej nad nimi refleksji. Wiemy przecież doskonale, że często samo życie wyprzedza refleksję i opis. Po trzecie wreszcie, pamiętajmy, że tak naprawdę próbujemy rekonstruować refleksję nad rolą świeckich lub ich faktyczne funkcje w konkretnych wspólnotach chrześcijańskich, a nie w całym Kościele antycznym. I po czwarte, nie możemy zapominać o różnicach zarówno kontekstu historycznego, jak też odmiennych form literackich użytych do opisu życia wspólnot 
chrześcijańskich w tekstach tzw. Ojców Apostolskich i Apologetów greckich II wieku.

Różnorodność ujęć i okazjonalność bezpośredniego pojawiania się naszej tematyki w interesujących nas dziełach, uniemożliwiają ujęcie całej problematyki tematycznie. Dlatego też po długich wahaniach zdecydowałem się w przypadku pism Ojców Apostolskich na analizę roli świeckich w tekstach poszczególnych autorów, natomiast w pismach Apologetów greckich II wieku na prezentację tylko syntetyczną.

\section{FUNKCJE ŚWIECKICH W PISMACH OJCÓW APOSTOLSKICH}

Powszechnie wiadomo, że pisma tzw. Ojców Apostolskich posiadają charakter typowo pastoralny, były adresowane do konkretnych wspólnot chrześcijańskich, które zamieszkiwały różne szerokości geograficzne ówczesnego Cesarstwa rzymskiego, dotyczyły zasadniczo okolicznościowych kwestii wewnątrzchrześcijańskich, a ich rysem charakterystycznym jest ciągle żywa pamięć o Jezusie historycznym oraz oczekiwanie na Jego Paruzję ${ }^{1}$. Najczęstszą, choć nie jedyną formą literacką przekazu kerygmatu chrześcijańskiego, był list wzorowany na Listach apostolskich Nowego Testamentu ${ }^{2}$. Pisma te pozostawały więc ciągle pod bardzo dużym wpływem zarówno treściowym, jak i formalnym nauczania apostolskiego, przekazanego w nauczaniu ustnym lub też w Nowym Testamencie.

Znaczenie i rola świeckich we wspólnotach Kościoła antycznego nie stanowią centralnego przesłania kerygmatu przekazanego nam w Nowym Testamencie ${ }^{3}$. Nie występuje też w nich sam grecki termin $\lambda \alpha u ̈ x o ́ s \varsigma^{4}$. Nie oznacza to jednak, że nasza tematyka jest zupełnie nieobecna na kartach Nowego Testamentu. Terminologia techniczna w nich nie występuje, ani też nasza tema-

${ }^{1}$ Por. podręczniki do patrologii: J. Quasten, Patrologia, I, Casale Monferrato 1980, 44-100; G. Bosio - E. dal Covolo - M. Maritano, Introduzione ai Padri della Chiesa, I, Torino 1993, 33-154; H. Drobner, Patrologia, Casale Monferrato, Brescia 1995, 161-174, 193-212; A.M. Malingrey, La littérature grecque chrétienne, Paris 1968, tłum. polskie M. Starowieyski, Chrześcijaniska literatura grecka, Tarnów 1995, 14-37, oraz polskie podręczniki: F. Drączkowski, Patrologia, Pelplin - Lublin 1998, 27-48; Sz. Pieszczoch, Patrologia, Gniezno 1998, 19-28; H. Pietras, Poczatki teologii Kościola, Kraków 2000, 13.26, a także studia szczegółowe: L.W. Bernard, Studies in the Apostolic Fathers and their Background, Oxford 1966; H. Lohmann, Drohung und Verheißung. Exegetische Untersuchungen zur Eschatologie bei den Apostolischen Vätern, Berlin 1989.

${ }^{2}$ Por. L. Małunowiczówna, Antologia listu starochrześcijańskiego, STCh 2, Lublin 1985, 24, choć oczywiście nie jedynie. Wystarczy wspomnieć Pasterza Hermasa, który należy do rodzaju literackiego apokalipsy.

${ }^{3}$ Por. M. Spinelli, Laico, DPAC II 1891-1893.

${ }^{4}$ Por. Konkordanz zum Novum Testamentum Graece, hrsg. K. Aland - H. Werner, Berlin New York 1987, 1093nn. 
tyka nie należy do centralnych, niemniej jednak niektóre teksty, szczególnie Listy apostolskie odnoszą się wyraźnie do różnych kategorii wiernych chrześcijan świeckich, takich jak np. wdowy, sieroty, niewolnicy, małżonkowie itd., i opisują ich zadania właśnie jako chrześcijan świeckich. Ponieważ ich rola została przedstawiona już wyżej w prezentacji „Świeccy w Kościele nowotestamentalnym", dlatego też pomijam tutaj to zagadnienie. Z perspektywy obecnych analiz warto jedynie podkreślić, że pisma tzw. Ojców Apostolskich kontynuują zasadniczo linię nowotestamentalną. Przyjrzyjmy się teraz poszczególnym tekstom.

1. Didache. Didache jest najstarszym dziełem należącym do pism tzw. Ojców Apostolskich, którego dokładny czas powstania nadal pozostaje trudny do ustalenia ${ }^{5}$. Dzieło to jest anonimową kompilacją różnych fragmentów, pochodzących najprawdopodobniej $z$ żywej tradycji różnych wspólnot chrześcijańskich i różnych epok ${ }^{6}$. Jedni badacze są zdania, że niektóre fragmenty Didache powstały bardzo wcześnie, bo już ok. 50-70 roku ${ }^{7}$, inni natomiast podkreślają aluzje do tekstów Nowego Testamentu, zwłaszcza Ewangelii wedlug Mateusza, Pasterza Hermasa czy Listu Barnaby, co według ich opinii dowodziloby powstania pisma w II wieku lub nawet później. Zbieżności te jednak dają się łatwo wyjaśnić wspólnym źródłem i niekoniecznie są dowodem na wzajemną zależność pism w obecnej ich formie ${ }^{8}$. Ostateczny redaktor pisma, prawdopodobnie judeochrześcijanin, piszący do pogan, połączył razem niektóre teksty użyteczne do pouczania nowych chrześcijan. Miałoby to miejsce, zdaniem większości specjalistów, pod koniec I wieku w rejonie Syrii zachodniej, może nawet w samej Antiochii lub Adiabene ${ }^{9}$. Ten swego rodzaju podręcznik wędrownego katechety chrześcijańskiego składa się z 16 rozdziałów, które dzielą się wyraźnie na 3 części: dwie drogi (rozdz. 1-6), przepisy liturgiczne i modlitwy (7-10), zasady dotyczące organizacji wspólnot (11-15) i zakończenie (16). J.P. Audet przekonująco wykazał, że dwie drogi swoją formą literacką są zbliżone do Reguty Zrzeszenia odnalezionej w Qumran, Listu Barnaby (18-20) i Doctrina Apostolorum. Byłby to również prawdopodobnie

5 Tekst zob. J.P. Audet, La Didachè des apôtres, Paris 1958; H. Lietzmann, Die Didache mit kritischen Apparat, Berlin 1962; W. Rordorf - A. Tuilier (ed.), La doctrine des douze Apôtres, SCh 248, Paris 1978; thum. polskie A. Świderkówna: Didache, w: Pierwsi Swiadkowie, BOK 10, Krak6́w 1998, 33-44.

${ }^{6}$ Por. zbiory opracowań w: C.N. Jefford, The Didache in Context. Essays on its Text, History and Transmission, Suppl. NT, Leiden 1995; J.A. Draper (red.), The Didache in modern Research, Leiden 1996.

7 Audet, dz. cyt. 187-206.

8 Por. R.A. Kraft, Barnabas and the Didache, New York 1965, 4-11.

9 Taka jest opinia większosci poważnych badaczy Didache: Audet, dz. cyt.; Rorsdorf, dz. cyt.; A. Adam, Erwägungen zur Herkunft der Didache, ZKG 65 (1957) 1-47; także M. Starowieyski, Podręczny zbiór praw gminy chrześcijańskiej - Didache, BOK 10, 25-31. 
najstarszy fragment Didache. Najbardziej interesująca dla naszych rozważań jest oczywiście część 3, gdzie opisane zostały różne funkcje we wspólnocie chrześcijańskiej.

Analizę szczegółową rozpoczniemy od odrzucenia błędnej, moim skromnym zdaniem, perspektywy interpretacji trzeciej części Didache jako fragmentu, który dotyczy kontrowersji pomiędzy charyzmatykami, a hierarchią kościelną. Przyjęcie bowiem takiego założenia, zresztą wcale tak do końca niezbyt oczywistego, już na wstępie niejako „ustawia” rozumienie i interpretację samego tekstu. To właśnie dla A. von Harnacka Didache wypełniałoby lukę pomiędzy charyzmatyczną strukturą Kościola przedstawioną choćby przez św. Pawła w 1 Liście do Koryntian, a strukturą hierarchiczną obecną w Listach pasterskich ${ }^{10}$. Jego więc zdaniem rozdz. 11-13 Didache mówiące o charyzmatykach, byłyby wcześniejsze od rozdz. 15 traktującego o hierarchii. Problem tylko w tym, że w Didache to napięcie nie wydaje się być rzeczywiście realnym, ani też wcześniejsze powstanie rozdz. 11-14 wcale nie jest takie oczywiste i domaga się uzasadnienia. Zamiast narzucania tekstowi sztucznych napięć, spróbujmy prześledzić jego wewnętrzną dynamikę taką, jaka prezentuje się nam w obecnej swej formie.

Analizę tematyki świeckich rozpocznijmy od stwierdzenia, że choć termin $\lambda$ גäxós w Didache nie pojawia się ${ }^{11}$, to jednak w owej trzeciej części autor przedstawia zasady postępowania właśnie chrześcijan wobec apostołów, proroków, nauczycieli biskupów i diakonów ${ }^{12}$. W rozdz. 11-13 podane zostały zasady odróżniania proroków prawdziwych od fałszywych i sposoby postępowania wobec nich, natomiast w rozdz. 14 - reguły dotyczące celebracji niedzielnej Eucharystii, zaś w 15, kryteria jakimi powinni charakteryzować się biskupi i diakoni. Didache nawiązuje tutaj niewątpliwie do Pawłowego rozróżnienia w 1 Kor 12, 28:

„I tak ustanowił Bóg w Kościele najprzód apostołów, po wtóre proroków, po trzecie nauczycieli, a następnie tych, co mają dar czynienia cudów, wspierania pomocą, rządzenia oraz przemawiania rozmaitymi językami"13.

Kategorie apostoł - prorok - nauczyciel są obecne również w Dziejach Apostolskich 11, 27 oraz 13, 1, i zdaniem Hammana byłyby najprawdopodobniej pochodzenia judaistycznego opartego na triadzie prawo - proroctwo - mądrość ${ }^{14}$. W Didache 11,3 i 13, 2-3 pojawiają się apostołowie i prorocy,

${ }^{10}$ Por. A. von Harnack, Die Lehre der zwölf Apostel, Leipzig 1884.

${ }^{11}$ Por. E.J. Goodspeed, Index patristicus sive Clavis Patrum Apostolicorum operum, Peabody 1993, 129.

12 W Pasterzu 13, 1 Hermasa pojawiają się natomiast „apostołowie, biskupi, nauczyciele i diakoni".

${ }^{13}$ Wszystkie cytaty biblijne według Biblii Tysiąclecia, Poznań - Warszawa 1982.

14 Por. A. Hamman, Profeta, DPAC I 2914. 
natomiast w 15, 2, podobnie jak w Pasterzu Hermasa, prorocy z nauczycielami. Mamy tutaj ślad organizacji wspólnot chrześcijańskich opartych na różnorodności posług (por. 1Kor 12, 4) ${ }^{15}$. Nie ma jednak racji Hamman, twierdząc, że została ona później zastąpiona w Didache 15, 1 przez biskupów i diakonów, gdyż to zakłada argumentację Harnacka, że rozdz. 15 jest późniejszy niż rozdz. 11-13, co wcale nie jest takie oczywiste i domaga się uzasadnienia. Spróbujmy pójść inną drogą, a mianowicie opisania poszczególnych charyzmatów.

Struktura przedstawiona w interesujących nas rozdziałach Didache odpowiada dokładnie tej, jaką mamy w 1 Kor 12, 28: apostołowie, prorocy, nauczyciele, biskupi (charyzmat rządzenia) i diakoni (charyzmat wspierania pomocą). Otóż, apostoł, to oczywiście nie jeden z Dwunastu Apostołów, ale po prostu ktoś posłany do głoszenia Ewangelii, prorok, natomiast, to człowiek mówiący pod natchnieniem Ducha Świętego, który zachęca, pociesza, rozpoznaje rzeczy zakryte teraźniejsze i przyszłe, wreszcie nauczyciel, to ktoś, kto posiada dar nauczania, a więc swego rodzaju lokalny katechista, biskup, to posiadający dar kierowania wspólnotą, a diakon, charyzmat wspierania pomocą. Nie wiadomo dokładnie dlaczego tylko te charyzmaty zostały wymienione, a inne pominięte ${ }^{16}$. Być może one właśnie były najbardziej użyteczne w życiu Kościoła tamtej epoki. Wszystko jednak komplikuje się jeszcze bardziej, jeśli pamiętamy, że autor Didache używa tych terminów zamiennie, w 11, 3 apostoł (ciągle pamiętajmy, że nie jest to termin techniczny na określenie Dwunastu, ale użyty w swoim podstawowym znaczeniu jako „posłany”) określany jest również prorokiem, w 13, 2 nauczyciel ma prawo do utrzymania na równi z prorokiem, natomiast w 15, 1 zostało wyraźnie podkreślone, że biskupi i diakoni pełnią posługę proroków i nauczycieli. Ma częściowo rację ks. M. Starowieyski, gdy stwierdza, że owe trzy kategorie charyzmatyków w Didache (apostołowie, prorocy, nauczyciele) dadzą się w sumie sprowadzić do jednej kategorii - proroków. W tej samej wspólnocie mogli przecież równie dobrze działać „charyzmatycy - prorocy apostołujący, nauczający, prowadzący modlitwy oraz hierarchia - biskupi i diakoni"17. Hipoteza ta nie wyjaśnia nam jednak do końca, dlaczego również biskupi i diakoni są określani jako pelniący posługę prorocką i nauczycielską oraz w sposób ukryty zakłada, że tylko biskupi i diakoni należeli do duchownych, natomiast apostołowie, prorocy i nauczyciele - nie. Na tym jednak nie koniec. Otóż, jak pamiętamy, w Didache 10, 7 autor zachęca, by prorokom pozwalać „odprawiać dziękczynienie jak długo zechcą”. Chodzi o celebrację Eucharystii, dziękczynienie po przyjęciu Eucharystii czy dziękczy-

${ }^{15}$ Por. A. Lemaire, Les ministèrs aux origines de l'Eglise, Paris 1971, 45nn.

${ }^{16} \mathrm{~W} 1$ Kor $12,7 \mathrm{n}$ św. Paweł wymienia takie dary: mądrości słowa, umiejętności poznawania, wiary, uzdrawiania, czynienia cudów, proroctwa, rozpoznawania duchów, języków i thumaczenie języków.

17 Por. M. Starowieyski, Podręczny zbiór praw gminy chrześcijańskiej, art. cyt., s. 30. 
nienie po posilku ${ }^{18}$ ? A jeśli tak, to rozróżnienie charyzmatycy - nie celebrujący Eucharystii i duchowni - celebrujący, nie funkcjonuje. Myślę zresztą, że fakt celebracji Eucharystii nie może być podstawą do rozróżniania pomiędzy duchownymi i świeckimi w Didache, gdyż czytając te fragmenty niejako automatycznie zaliczamy diakonów do duchownych, choć Eucharystii najprawdopodobniej oni nie celebrowali.

Być może wyjściem $\mathrm{z}$ tej patowej sytuacji byłoby przyjęcie hipotezy, że dla autora Didache prorok jest swego rodzaju kategorią ogólną, która obejmowała różne posługi w Kościele antycznym. Prorok to chrześcijanin otwarty na działanie i natchnienie Ducha Bożego, który powołuje go do spełniania różnych posług we wspólnocie. Te posługi może on pełnić jako osoba świecka lub członek hierarchii. Jako duchowny celebruje Eucharystię (składa dziękczynienie w 10,7 ) oraz pełni posługę rządzenia (biskup) lub pomocy potrzebującym (diakona), natomiast jako osoba świecka głosi kerygmat ewangeliczny (apostoł - posłany), rozeznaje ukrytą rzeczywistość duchową teraźniejszą i przyszłą (prorok) oraz naucza (nauczyciel). Raz więc termin prorok byłby używany jako kategoria ogólna obejmująca wszystkich otwartych na działanie Ducha Bożego, innym razem natomiast już jako specyficzny charyzmat tylko prorocki. Nie wydaje się natomiast, by można było traktować te fragmenty jako dowód na to, że w Kościele antycznym świeccy głosili kazania lub homilie. Tekst nic nie mówi o kontekście liturgicznym, i chodzi raczej o głoszenie Ewangelii w sensie ogólnym. Nie wyklucza to oczywiście faktu, że biskup i diakon mogą być obdarzeni również charyzmatem prorockim i nauczycielskim, by pełnić te posługi we wspólnocie, tekst jednak nie mówi nic by apostoł, prorok lub nauczyciel pełnili biskupią posługę rządzenia lub diakońską pomocy potrzebującym. Narzucam tutaj oczywiście tekstowi późniejsze rozróżnienie na świeckich (apostołowie, prorocy, nauczyciele) i hierarchię (biskup i diakon), gdyż z samego tekstu nie wynika to w sposób jasny. Nie ma niestety innej możliwości, by próbować rozwikłać zagadki Didache. Nie jest to zresztą tak do końca „,narzucanie" zupełnie arbitralne, gdyż późniejszy kierunek interpretacji tych funkcji w Kościele (por. np. 1 List do Koryntian Klemensa Rzymskiego) oraz ich wcześniejsza prezentacja w Listach pasterskich Nowego Testamentu zdaja się potwierdzać takie właśnie ich rozumienie w Didache.

Dopiero na takiej bazie można zastanawiać się nad rolą świeckich w Kościele w Didache. W naszych fragmentach owa rola sprowadzałaby się do trzech zasadniczych elementów: po pierwsze rozeznawać rzeczywisty charyzmat proroka wędrownego, który przychodzi do wspólnoty, albo też pomiędzy rzeczy-

${ }^{18}$ Możliwe jest jedno i drugie znaczenie, gdyż choć zarówno w Nowym Testamencie (1 Kor

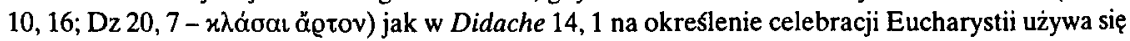
terminów „łamać chleb”, to jednak również w Didache 14,1 dołączone jest określenie „składać dziękczynienie". 
wistym uczniem Pana a fałszywym chrześcijaninem, po drugie, dać utrzymanie prawdziwym prorokom, i po trzecie brać udział w wyborze biskupów i diakonów. Zobaczmy je jednak dokładniej.

Autor podaje najpierw kryteria, za pomocą których można odróżnić nauczyciela, proroka i apostoła prawdziwego od fałszywego: jeśli zacznie coś zmieniać i wykładać inną naukę po to, żeby burzyć, jeśli pozostanie dłużej niż dwa dni, żąda pieniędzy na drogę, nie żyje na sposób Pana, każe zastawić stół i sam z niego spożywa, nie postępuje zgodnie z tym, co naucza, jeśli, rzekomo pod natchnieniem Ducha domaga się pieniędzy - jest to fałszywy prorok. Fałszywym zaś uczniem Pana, który kupczy Chrystusem jest ktoś, kto chce żyć bezczynnie i być utrzymywanym przez wspólnotę ${ }^{19}$. Tekst nawiązuje tutaj prawdopodobnie do sytuacji, kiedy to niektórzy pseudo-prorocy wędrowni wykorzystywali naiwność chrześcijan i podając się za proroków chrześcijańskich pozostawali na utrzymaniu wspólnoty. Taka sytuacja miała zapewne miejsce, skoro opisuje ją Lukian z Samosaty w dziele De morte Peregrini, choć trudno określić, czy owa naiwna gościnność chrześcijan była zjawiskiem nagminnym czy też sporadycznym.

Prawdziwy natomiast prorok według autora, czyli taki, który przybywa głosić Ewangelię, zasługuje na przyjęcie ,jak sam Pan” $(11,4)$, zostaje we wspólnocie najdlużej dwa dni, na drogę jest wyposażony tylko w chleb, żyje na sposób Pana i zgodnie $\mathrm{z}$ tym, czego sam naucza, troszczy się o ubogich i potrzebujących ${ }^{20}$. Choć autor wyraźnie zaznacza, że „nie każdy, kto mówi pod natchnieniem Ducha jest prorokiem. Jest nim tylko wtedy, gdy żyje na sposób Pana" $(11,8)$, to jednak podkreśla równiez:

„Nie wystawiajcie na próbę żadnego proroka, który mówi pod natchnieniem Ducha, bo każdy grzech może być odpuszczony, lecz ten grzech odpuszczony nie będzie" ${ }^{\text {21 }}$.

W przypadku natomiast relacji do innych chrześcijan, zasada rozeznawania gościnności i pomocy polega na znalezieniu zajęcia, ale nie może być naiwnym przechowywaniem tych, którzy kupczą Chrystusem $(12,1-5)$

Po drugie, wspólnota postara się podzielić częścią swoich dóbr z prawdziwym prorokiem i nauczycielem. Poświęcony jest temu cały rozdz. 13, w którym autor podkreśla, że prawdziwy prorok i nauczyciel „wart jest swojej strawy”. Zachęca więc wiernych chrześcijan do podzielenia się z nimi pierwocinami, jakie uznają za stosowne, nie odmawiając wina, oliwy, ziarna, chleba, bydła i owiec, pieniędzy, ubrania i wszystkiego, co posiadają. Widać więc wyraźnie, że

${ }^{19}$ Por. Didache $11,2-12,1$ passim.

${ }^{20}$ Por. Didache 11, 2-12, 1 passim.

${ }^{21}$ Didache 11, 7, SCh 248, 184, BOK 10, 38; zob. także W. Turek, Grzech przeciw Duchowi Świętemu w tradycji patrystycznej, Kraków 2000, 50-53. 
autor stosuje tutaj do chrześcijańskich proroków i nauczycieli zasady starotestamentalne, stąd określenie ,oni bowiem są waszymi arcykapłanami” $(13,3)$ niekoniecznie jest późniejszą interpolacją, jak przypuszczał Audet ${ }^{22}$, gdyż nie chodzi tu o przypisanie ich do hierarchii, lecz danie im prawa do pierwocin z dóbr, jak w przypadku arcykapłanów Starego Testamentu.

Trzecią wreszcie rolę, jaką mają do spełnienia laicy wspólnoty, jest wybór biskupów i diakonów:
„Wybierzcie zatem sobie biskupów i diakonów godnych Pana, ludzi cichych, spokojnych, bezinteresownych, wiarygodnych i wypróbowanych. Oni bowiem pelnią u was także posługę proroków i nauczycieli. Nie gardźcie więc nimi, gdyż należy im się wśród was to samo poważanie, co prorokom i nauczycielom" ${ }^{\text {"23 }}$.

Autor podaje również cechy, jakimi powinni charakteryzować się ewentualni kandydaci: cichość, spokój, bezinteresowność, wiarygodność i wypróbowanie. Należy im się takie samo poważanie, jak prorokom i nauczycielom. Ten fragment Didache jest także najstarszym pismem wczesnochrześcijańskim, potwierdzającym praktykę wyboru biskupów i diakonów przez świeckich czlonków wspólnoty. Nie znajdujemy niestety opisu, jak to wszystko wyglądało w praktyce.

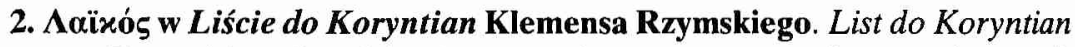
Klemensa Rzymskiego jest, jak wiemy, zarówno w antycznych manuskryptach jak też najstarszych dokumentach Kościoła przypisywany jednogłośnie Klemensowi ${ }^{24}$, którego Ireneusz określa wyraźnie jako trzeciego następcę św. Piotra na stolicy biskupiej w Rzymie ${ }^{25}$, prawdopodobnie w latach 90/92101. Ponieważ autor Listu wspomina (I 1) o nieszczęściach, jakie spadty na jego wspólnotę, co najczęściej łączy się z prześladowaniem chrześcijan rzymskich za Domicjana (81-96); stąd też istnieje duże prawdopodobieństwo, iż list ten został napisany ok. $96 / 97$ roku.

Dosyć jednorodny charakter Listu wskazuje, iż jego autorem jest jedna osoba. I choć czasami autor pisze o sobie w liczbie mnogiej, to jest to raczej chęć podkreślenia, że pisze w imieniu całej wspólnoty Kościoła rzymskiego, niż wskazówka, by doszukiwać się kilku poziomów redakcji pisma ${ }^{26}$. Trudno natomiast cokolwiek więcej powiedzieć na temat samego autora. Niewykluczone, że był nim rzeczywiście Klemens, towarzysz św. Pawła wspominany w Flp 4, 3, choć pozostaje to nadal w sferze przypuszczeń trudnych do zweryfikowania.

22 Por. Audet, dz. cyt., s. 105.

23 Didache 15, 1-2, SCh 248, 192-194, BOK 10, 40.

24 Tekst listu: Clément de Rome, Epître aux Corinthiens, ed. A. Jaubert, SCh 167, Paris 2000, thum. pol. A. Świderkówna, BOK 10, 51-87.

${ }_{25}$ Por. Adversus haereses III 3, 3.

${ }^{26}$ Por. H. Drobner, Patrologia, s. 100. 
Opis harmonii świata wskazuje, że Klemens był obeznany z kulturą helleńską, choć znowu trudno byłoby ustalić stopień gruntowności jego wiedzy w dziedzinie filozofii antycznej. W tamtym czasie, każdy wykształcony człowiek znał kulturę helleńską. $Z$ drugiej natomiast strony, Klemens znał również dosyć dobrze Stary Testament, który cytuje często za tekstem hebrajskim lub za Septuagintą ${ }^{27}$. Niewykluczone więc, że autor był Żydem z pochodzenia. Klemens jest jednak przede wszystkim chrześcijaninem, który korzysta $\mathrm{z}$ filozofii greckiej, a Stary Testament interpretuje na sposób właśnie chrześcijański ${ }^{28}$.

Bezpośrednim motywem napisania Listu było zdjęcie $\mathrm{z}$ urzędu dotychczasowych prezbiterów dobrze sprawujących swój urząd i prawdopodobne zastąpienie ich nowymi, młodszymi, co wywołało sprzeciw części wspólnoty i w konsekwencji podział. Wydarzenie to musiało odbić się dużym echem w całym ówczesnym świecie chrześcijańskim i niejako zmusiło Klemensa do interwencji w imię Kościoła rzymskiego. Można by więc powiedzieć, że niejako pierwszą funkcją pewnej grupy świeckich w Koryncie było niesłuszne przypisywanie sobie władzy zdejmowania $\mathrm{z}$ urzędu prezbiterów, zaś pozytywna rola pozostałych polegałaby na nagłośnieniu sprawy, łącznie z przekazaniem informacji do Kościoła w Rzymie. Wrócimy jednak do tego jeszcze w dalszej części naszych analiz.

Na strukturę Listu składa się 65 rozdziałów, które z kolei można podzielić na 6 części: Prolog (1-3), I - prezentacja cnót do praktykowania (4-21), II - Bóg jest wierny sercom niepodzielnym (2-36), III - dyscyplina we wspólnocie (37-44), IV - ostrzeżenia (45-59, 1), V - zakończenie $(59,2-61)^{29}$. Najbardziej interesująca dla nas jest część III, która dotyczy dyscypliny we wspólnocie i może być podzielona jeszcze dodatkowo na dwie części: wzajemne poddanie się sobie (37-39) oraz rozdziały 40-44, przedstawiające hierarchię kościelną wzorowaną na hierarchii lewitów w Starym Testamencie. W rozdziałach 3739 Klemens opisuje życie chrześcijan w kategoriach militarnych, jako walkę pod rozkazami Chrystusa, która domaga się odpowiedniego zdyscyplinowania, uległości i posłuszeństwa w wypełnianiu poleceń. Podkreśla, że choć w armii istnieją różne funkcje, to jednak „każdy na swoim posterunku wypełnia rozkazy cesarza i swoich dowódców" $(37,3)$. Wielki pożytek dla wszystkich wynika $z$ tego, ze jeden drugiemu jest potrzebny. Odwołanie się również w dalszej części do przykładu harmonii ciała ludzkiego jest tak naprawdę wołaniem o ,naturalne” posłuszeństwo:

${ }^{27}$ Por. D.A. Hagner, The Use of the Old and New Testament in Clement of Rome, Leiden 1973.

${ }^{28}$ Por. M. Starowieyski, Interwencja biskupa Rzymu - św. Klemens Rzymski, BOK 10, 45-50, zwł. 48.

${ }^{29}$ Korzystam tutaj z podziału zaproponowanego przez A. Jaubert, Introduction, SCh 167 , 25-27. 
„Nawet nasze najmniejsze członki potrzebne są i pożyteczne dla calego ciała. Wszystkie wspólnie oddychają i współpracują ze sobą w jednomyślnym posłuszeństwie dla zachowania jedności ciała"30.

Na tej podstawie Klemens przechodzi dalej do Ciała Chrystusa, czyli Kościoła, w którym również powinna panować jedność tzn. posłuszeństwo każdego temu z braci, ,który został obdarzony stosownym charyzmatem" $(38,1)$. Wszystko bowiem, bogactwo, ubóstwo, pokora czy czystość jest darem Boga. Bezrozumnymi i bezmyślnymi natomiast są ci, którzy próbują wywyższać się własnym zamysłem wiedząc, że człowiek jest tak naprawdę tylko prochem $(39,1 \mathrm{nn})$. Kolejne rozdziały 40-44 mówią o pewnym porządku w chrześcijańskiej slużbie Bożej. Klemens podkreśla, że ci, którzy wniknęli w głębiny Bożej wiedzy powinni czynić wszystko w należytym porządku i zgodnie z poleceniem Pana $(40,1)$.

„Rozkazał On, by ofiary i cała służba Boża odbywały się nie przypadkowo i bezladnie, lecz w określonych czasach i godzinach. Gdzie i przez kogo mają byé sprawowane, On sam wyznaczył swoim najwyższym postanowieniem, aby wszystko odbywało się w sposób święty zgodnie z jego życzeniem i miły Jego woli" ${ }^{31}$.

Klemens podkreśla więc, że to sam Bóg wyznaczył, gdzie, kiedy i przez kogo mają być składane ofiary i pełniona służba Boża. Odrzucenie Jego postanowień w tym względzie jest w konsekwencji odrzuceniem Jego woli. Ci natomiast, którzy stosują się do poleceń Pana i składają ofiary w wyznaczonym czasie, są Mu mili. Ponieważ Klemens bardzo mocno akcentuje ten wątek, więc niewykluczone, że być może konflikt we wspólnocie korynckiej dotyczył właśnie miejsca i czasu składania Ofiary Eucharystycznej lub w ogóle pełnienia służby Bożej. Gdy prezbiterzy nie chcieli przystać na proponowane zmiany, zostali odsunięci od pełnienia urzędu; i najbardziej interesujący nas fragment:

„Arcykapłanowi bowiem zlecona została właściwa mu służba Boża, kapłanom zostało wyznaczone właściwe im miejsce i lewitów powołano do właściwej im posługi. Człowieka świeckiego wiążą prawa właściwe świeckim"32.

Jak już pisałem wyżej, List do Koryntian jest najstarszym tekstem wczesno-

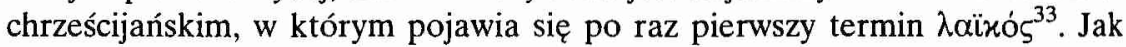
rozumie autor ten termin? Dla Klemensa jest to ktoś różny od arcykapłana,

${ }^{30}$ Epistola ad Corinthios 37, 5, SCh 167, 162, BOK 10, 68.

31 Tamze 40, 2-3, SCh 167, 167, BOK 10, 69.

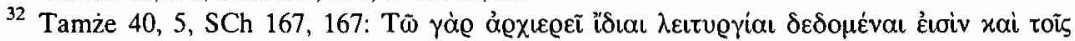

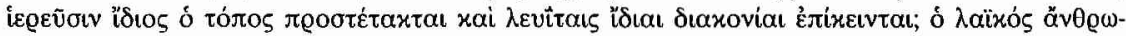

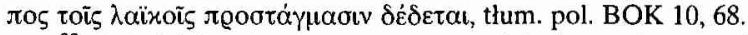

33 Zob. M. Jourjon, Les premiers emplois du mot laï dans la littérature patristique, „Lumière et Vie" 65 (1963) 37-42. 
kapłana i lewity. Jak widać wyraźnie, pozostajemy tutaj w obrębie nie tylko terminologii, ale również eklezjologii opartej na Starym Testamencie. Historia zbawienia, dopełniona w Ofierze Jezusa Chrystusa, nie polegała na odrzuceniu Prawa Mojżeszowego, ale na posłusznym wypełnieniu go aż do końca. Chrystus zainicjował nowy, ostatni etap tej historii, i choć chrześcijanie są nowym ludem, to jednak istnieje ciaglość pomiędzy strukturami narodu wybranego i nowego ludu. Porównanie, jakiego dokonuje Klemens w rozdzialach 40-41 pomiędzy hierarchią Starego Testamentu, a strukturami kościelnymi, wskazuje na duży wpływ środowisk lewitów na jego rozumienie struktury Kościoła. Jak w Starym Testamencie, tak również i obecnie, życie liturgiczne wspólnoty musi się odbywać według określonych zasad (taxis). Ma niewątpliwie rację A. Jaubert, gdy twierdzi, że odwołanie się Klemensa do owej taxis liturgicznej nie pochodzi ze stoicyzmu, ale raczej z kręgów kapłańskich i lewickich, jak to potwierdza Testament Lewiego i Testament Neftalego z Testamentów Dwunastu Patriarchów $w^{34}$. Jeśli więc Klemens opisuje różne kategorie ludzi we wspólnocie, czyni to $w$ oparciu o role, jakie mieli oni do spełnienia wlaśnie w kulcie. Kontekst kultyczny jest więc fundamentalny przy próbie zrozumienia znaczenia terminu

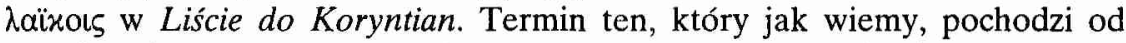

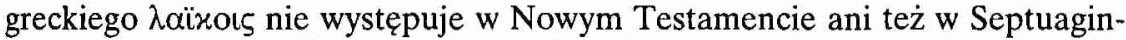
cie. Natomiast użycie $\lambda \alpha$ ó w Jr 34, 19 (LXX) i Dz 13, 1 zdaje się wskazywać na kogoś, kto nie pełni żadnej posługi na rzecz wspólnoty. W późniejszych tłumaczeniach greckich Starego Testamentu, jak Aquila, Symmach czy Teodocjon termin $\lambda \alpha$ aïxoı odnosi się do sfery profanum jako przeciwieństwa do sacrum $^{35}$. Dla Klemensa więc termin $\lambda$ aïxoıৎ oznaczałby właśnie kogoś, kto nie jest kapłanem ani lewitą, nie pełni więc żadnej roli w kultycznym składaniu ofiar. Czy jednak według Klemensa takie starotestamentalne rozumienie tego terminu wyczerpuje rolę świeckich w Kościele?

Dalej, w rozdz. 42-43 wyjaśnia on powszechnie znane zasady funkcjonowania sukcesji apostolskiej: Bóg Ojciec posłał Jezusa Chrystusa - On wybrał apostołów - apostołowie wypróbowane „primicje” swojej ewangelizacji, i polecili, by po ich śmierci zostali wybrani inni wypróbowani ludzie. W kontekście naszych analiz warto podkreślić, iż Klemens, podobnie jak autor Didache, widzi aktywną rolę wspólnoty w wyborze biskupów. Potwierdza to następujący tekst:

„Uważam zatem, że nie jest rzeczą słuszną odsuwać od tej posługi ludzi, którzy wyznaczeni przez Apostołów lub też później przez innych wybitnych mężów, za

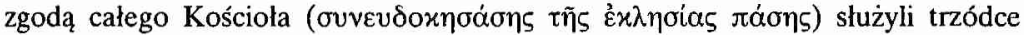
Chrystusowej w sposób nienaganny, z pokorą i spokojem, bez małostkowości,

${ }^{34}$ Por. A. Jaubert, Introduction, SCh 167, 80-81. W dalszej części analiz korzystam również $z$ wniosków tej autorki.

${ }^{35}$ Por. A. Jaubert, SCh 167, 167, przypis 5: np. w 1Krl 21, 6 określenia „chleb zwyczajny” w odróżnieniu od „chleba poświęconego”, czy Ez 22, 26 (Symmach) lub 48, 15 (Symmach, Teodocjon). 
i którym od dawna wszyscy dają dobre świadectwo. I nie mały byłby to błąd pozbawiać godności biskupiej tych, co składają Bogu ofiary w nieskazitelnej pobożności" ${ }^{36}$.

Klemens nie ma tutaj oczywiście na myśli całego Kościoła, ale całą wspólnotę lokalną. Wybiera ona lokalnego biskupa i jest to wybór na cale jego życie. Jeśli zachowuje się godnie, nienagannie, pokornie, spokojnie i pobożnie oraz ma dobre świadectwo, popełniają poważny błąd ci, którzy chcieliby go pozbawić jego funkcji przewodzenia wspólnocie. Klemens daje więc bardzo duże uprawnienia wspólnocie świeckich wierzących, a w konsekwencji każdemu jej członkowi, gdy chodzi o wybór biskupa, ale też jednocześnie zakreśla granice tych uprawnień. Wspólnota tylko wybiera i niejako proponuje kandydata, natomiast władza w Kościele jest przekazywana dzięki sukcesji apostolskiej za pośrednictwem apostołów i ich następców. Wspólnota, ani żaden jej poszczególny członek, nie mają natomiast uprawnień odebrania posługi biskupiej komuś, kto spełnia ją godnie.

Klemens opisuje więc rolę świeckich w wyborze duchownych i jednocześnie zakreśla granice tych uprawnień w Kościele lokalnym. Podstawą takiego opisu był termin $\lambda$ aïxoı jako określenie kogoś, kto nie sprawuje posługi składania ofiary w imieniu wspólnoty.

3. II List do Filipian Polikarpa ze Smyrny. Zauważone już w XVII wieku drobne sprzeczności pomiędzy rozdz. 9, w którym autor zdaje się znać los Ignacego z Antiochii, a rozdz. 13 Listu do Filipian Polikarpa ze Smyrny, w którym pyta o jego ostateczne dzieje, doprowadzily niektórych badaczy do zakwestionowania autentyczności tego pisma. Inne natomiast rozwiązanie zaproponował P.N. Harrison, postulując istnienie tak naprawdę dwóch listów Polikarpa do Filipian: 1 List, to krótka informacja zawarta w obecnym rozdz. 13 przesłana adresatom wraz z kolekcją niektórych listów Ignacego, zaś 2 List to pozostała część obecnego Listu do Filipian ${ }^{37}$. Hipoteza Harrisona zyskała aprobatę większości badaczy. Nie podzielono jednak opinii o ewentualnej dacie powstania 2 Listu do Filipian, którą Harrison umieszcza na końcowe lata panowania Hadriana, czyli lata 135-137. Jeśli 1 List powstałby krótko po pobycie Ignacego w Smyrnie, to 2 List do Filipian zostałby napisany najprawdopodobniej niedługo po pierwszym ${ }^{38}$, czyli ok. 108-110 roku.

${ }^{36}$ Epistola ad Corinthios 44, 3, SCh 167, 172, BOK 10, 71.

${ }^{37}$ Por. P.N. Harrison, Polycarp's two Epistles to the Philippians, Cambridge 1937.

${ }^{38}$ Por. P.T. Camelot, Introduction, w: Ignace d'Antioche. Polycarpe de Smyrne. Lettres. Martyre de Polycarpe, ed. P.T. Camelot, SCh 10bis, Paris 1998, 159-171, zwl. 164-167. W moich poprzednich opracowaniach na temat Listu di Filipian Polikarpa ze Smyrny pisałem zawsze o jednym liście, tutaj przyjmuję za większością badaczy dwa listy, choć tak naprawdę nie jestem jeszcze w pełni przekonany do hipotezy Harrisona. Pozorna sprzeczność pomiędzy rozdz. 9 i 13 nie 
Polikarp nie pisze, to prawda, nic bezpośrednio o roli świeckich w swojej wspólnocie ani też we wspólnocie w Filippi, do której adresował swoje dwa swoje Listy. Przedstawia natomiast na wzór zachęt Apostoła Pawła i innych pisarzy swojej epoki zadania i rolę jaką mają do spełnienia poszczególne grupy chrześcijan zarówno świeckich, jak i duchownych ${ }^{39}$. Nie chodzi oczywiście o ich rolę liturgiczną, a raczej o rolę, jaką mają do spełnienia we własnych rodzinach, życiu wspólnoty oraz $\mathrm{w}$ relacji do pogan. Polikarp zachęca więc najpierw do trwania $w$ cnotach, zwłaszcza w wierze, nadziei i milości oraz unikania wszelkiego grzechu $(3,3)$. Wszyscy mają do spełnienia podstawowe zadanie: żyć zgodnie z przykazaniami i w sposób godny chwały Bożej dając świadectwo Ewangelii ${ }^{40}$.

W 2 Liście do Filipian 4-6 Polikarp opisuje zadania, jakie mają do spełnienia żony, wdowy, diakoni, młodzież, dziewice i prezbiterzy. Choć biskup Smyrny nie używa oczywiście żadnych określeń typu „laik” - „duchowny”, to jednak diakonom i prezbiterom przypisuje wyraźnie funkcje przewodzenia we wspólnocie, natomiast żony, wdowy, młodzież i dziewice traktuje jako „świeckich”. W prezentacji swoich pouczeń dla poszczególnych grup wiernych chrześcijan Polikarp inspiruje się wyraźnie tekstami Nowego Testamentu (Ef 5, 21n; 6, 4; Kol 3, 18n; 1Tm 3, 2-7; Tt 1, 6-9), a także Listem do Koryntian $(1,3 ; 21,6-8)$ Klemensa Rzymskiego i Ignacego Do Polikarpa $(5,1)$. O żonach pisze tak:

„Potem nauczcie i wasze żony [zachowywać] daną im wiarę, miłość i nieskazitelność, kochać własnych mężów w doskonałej wierności i kochać również wszystkich jednakowo w sposób całkowicie czysty, a dzieci swoje wychowywać w bojaźni Bożej" ${ }^{\prime 1}$

Choć Polikarp nawiązuje tutaj do wspomnianych wyżej tekstów Nowego Testamentu i wczesnochrześcijańskich, to jednak nie czyni tego w sposób niewolniczy, lecz twórczy. Rozpoczyna od podkreślenia kluczowej roli wiary i miłości w życiu kobiet chrześcijańskich. Pomija całkowicie tematykę poddania żon mężom, tak ważną choćby w Liście do Efezjan i Kolosan, nawiązuje natomiast do czystości i wierności z $1 \operatorname{Tm} 3,11$, nieskazitelności życia, miłości do mężów oraz szczerej miłości do wszystkich i chrześcijańskiego wychowywania dzieci z Listu do Koryntian $(1,3 ; 21,6-8)$ Klemensa Rzymskiego. Zasadniczą więc rolą, jaką mają do spełnienia chrześcijańskie żony, jest świadectwo wiary,

jest aż tak wielka, jak się ją przedstawia, a pytanie o „coś pewnego” na temat Ignacego i jego towarzyszy jest na tyle szerokie, by można było je z powodzeniem pogodzić z opisem ich losu w rozdz. 13. Kwestia ta wymaga jednak odrębnych analiz.

39 Por. M. Spinelli, Laico, w: DPAC II 1891-1893.

${ }^{40}$ Zob. A.V. Seumois, L'apostolat laíc dans l'antiquité selon les témoignages patristiques, „Euntes Docete" 1 (1952) 126-133.

${ }^{41} 2$ Epistola ad Philippenses 4, 2, SCh 10bis, 180, thum. A. Swiderkówna, BOK 10, 157 $z$ drobną zmianą: үuvaĩxa tłumaczę jako „żony”, a nie jako „kobiety”. 
wierność, miłość do mężów i innych ludzi w sposób czysty oraz wychowywanie dzieci zgodnie z zasadami Boga.

O wdowach biskup Smyrny pisze natomiast tak:

„Wdowy niech będą mądre w wierności, jaką winne są Panu, niech modlą się nieustannie za wszystkich, trzymając się $\mathrm{z}$ dala od wszelkiej obmowy, oszczerstwa, fałszywego świadectwa, zachłanności na pieniądze i zła każdego. Niech wiedzą, że są ołtarzem Boga" ${ }^{42}$.

Polikarp parafrazuje tutaj myśl obecną w 1 Tm 5, 3-16 i Tt 2, 3-4, zachęcając wdowy do wierności wybranemu stanowi wdowieństwa, ciąglej modlitwy, unikania plotek, obmów, oszczerstw, zachłanności i chciwości. Wyrażenie „ołtarz Boży" oznacza najprawdopodobniej tak, jak później u Tertuliana ${ }^{43}$ fakt, iż wdowy pozostawały na utrzymaniu wspólnoty: składano im ofiary jako dar Bogu.

O młodzieży nasz biskup wyraża się natomiast następująco:

„Tak samo młodzież niech będzie bez zarzutu w każdej sprawie, przede wszystkim strzegąc czystości i powstrzymując się od zła wszelkiego" ${ }^{44}$.

W dalszej części autor zachęca młodzież do powstrzymywania się od pożądań tego świata, zwłaszcza rozpusty i rozwiązłości oraz do poddania się „kapłanom i diakonom jak Bogu i Chrystusowi”. Polikarp łączy w tym tekście napomnienia przekazane przez Tt 2,6; 1 P 2,11;5,5, a według niego młodzież chrześcijańska powinna odróżniać się od pogańskiej unikaniem wszelkiego rodzaju rozpusty i rozwiązłości cielesnej. Natomiast w poddaniu się kapłanom i diakonom nie chodzi wcale o jakieś ubezwłasnowolnienie, ale kierowanie się w życiu zasadami Ewangelii przez nich nauczanymi.

Wreszcie „dziewice powinny żyć z sumieniem czystym i bez skazy"45. Polikarpa zachęca do wierności swojemu stanowi te kobiety, które wybrały życie w dziewictwie. Fragment ten niekoniecznie jest dowodem na istnienie już zorganizowanego życia mniszego, gdyż w tym czasie mogło chodzić jeszcze o wybór życia w dziewictwie bez opuszczania domu i swoich dotychczasowych zajęć. Biskup Smyrny opisuje więc niejako rolę świeckich chrześcijan w świecie, którzy są powołani do dawania swoim życiem świadectwa Ewangelii i wierności wybranemu bądź aktualnemu stanowi ich życia (żony, wdowy, młodzież i dziewice).

4. „Swiecki” jako odbiorca objawienia Bożego w Pasterzu Hermasa. Na pierwszy rzut oka mogłaby się wydawać co najmniej dziwna próba analizy

\footnotetext{
${ }^{42}$ Tamże 4, 3, SCh 10bis, 182, BOK 10, 157.

43 Por. Ad uxorem I 1.

442 Epistola ad Philippenses 5, 3, SCh 10bis, 182-184, BOK 10, 158.

45 Tamże 5, 3, SCh 10bis, 184, BOK 10, 158.
} 
Pasterza Hermasa z perspektywy pytania o rolę świeckich we wspólnocie, którą tekst nam opisuje. Nie znajdziemy w nim, to prawda, żadnych wskazówek na temat roli świeckich w ogóle, ani też opisu zadań poszczególnych grup we wspólnocie rzymskiej, gdzie pismo powstało, niemniej jednak tekst ten jest intrygujący z zupelnie innego powodu. Otóż, wiemy, że Pasterz jest pismem o charakterze apokaliptycznym, którego tematem centralnym jest rozumienie natury Kościoła i jego wladzy nad ludzkimi grzechami, natomiast wątkiem wiodącym tzw. paenitentia secunda, czyli możliwość drugiej pokuty po chrzcie świętym ${ }^{46}$. Jeśli więc Hermas jako osoba świecka (czyli nie należąca do hierarchii kościelnej) otrzymuje niebiańskie objawienia, które nie tylko dopuszczają, ale wręcz zobowiązują go do głoszenia możliwości drugiej pokuty po chrzcie świętym, korygując $w$ ten sposób dotychczasową praktykę kościelną $w$ tym względzie, to bylaby to bez wątpienia sprawa o fundamentalnym znaczeniu. Gdybyśmy bowiem w taki właśnie sposób pojmowali rolę Hermasa, to należałoby w nim widzieć prekursora roli świeckich w Kościele, jako przekazicieli Bożego przesłania, wspomagającego w jakimś sensie rozumienie objawienia publicznego i nauczanie Kościoła w niektórych aspektach, jak choćby w przypadku św. Bernadetty Soubirous czy św. Faustyny. Kwestia ta nie jest jednak wbrew pozorom taka prosta i łączy się z pytaniem o rzeczywistą naukę pokutną Pasterza, tak przecież różnie rozumianą przez badaczy tego pisma. Ponieważ w samym tekście Pasterza znajdziemy bardzo niewiele na interesujący nas temat, poprzestanę na kilku uwagach natury ogólnej, koncentrując się na pytaniu o rzeczywisty charakter nauki pokutnej autora.

Rozpocznijmy od podstawowego stwierdzenia, a mianowicie, iż wszystko wskazuje na to, że Hermas nie należał do hierarchii kościelnej ${ }^{47}$. Nie można oczywiście o tym wnioskować tylko na podstawie faktu, iż posiadał żonę i dzieci, gdyż w II wieku nie było to kryterium rozstrzygające. Wnioskujemy o tym natomiast $\mathrm{z}$ faktu, ze wielokrotnie otrzymuje on polecenie powiadomienia o głoszonej przez siebie nauce pokutnej przełożonych i starszych (prezbiterów) Kościoła $(6,6 ; 8,2-3)$ wraz z podkreśleniem, iż te zasady pokutne obowiązują również ich samych. Hermas nie jest więc duchownym, lecz prorokiem, który ma za zadanie przekazanie przesłania $\mathrm{z}$ nieba dotyczącego pokuty wszystkim chrześcijanom. Bez ostatecznego rozstrzygania, czy ta inspiracja była rzeczywista czy tylko pozorna, misję Hermasa musimy więc rozumieć w kontekście wczesnochrześcijańskiej charyzmatycznej posługi świeckich w Kościele. Dalej, z tekstu wynika wyraźnie, że dla autora tematem wiodącym jest właśnie kwestia

${ }^{46}$ Pomijam tutaj wszelkie informacje wstępne o samym dziele, autorze, dacie i miejscu powstania, które zob. R. Jolly, Introduction, w: Le Pasteur, SCh 53bis, 2 ed., Paris 1998, 11-74 wraz. $\mathrm{z}$ bibliografią; M. Starowieyski, $W$ kręgu chrześcijańskiego wizjonerstwa-Hermas, w: Pierwsi Świadkowie, BOK 10, Kraków 1998, 205-210; F. Szulc, Spór o „Pasterza” Hermasa, VoxP 2 (1982) z. 3, 340-355 oraz opracowania podręcznikowe.

${ }^{47}$ Takiego zdania jest choćby R. Jolly, Introduction, w: Le Pasteur, SCh 53bis, 11. 
pokuty ${ }^{48}$. I na tym właściwie kończy się, niestety, consensus badaczy Pasterza. W interpretacji nauki pokutnej dzieła dominują dwie zasadnicze teorie. Pierwsza, tzw. Tauftheorie, głosi, że w Kościele antycznym II wieku istnial rygoryzm penitencjalny, według którego tylko chrzest gladzi wszystkie popełnione wcześniej grzechy, natomiast po jego przyjęciu chrześcijanie są wezwani do życia bezgrzesznego. Jeśli więc ktoś zgrzeszył ciężko po chrzcie, nie było już dla niego żadnego ratunku na ziemi i pozostawało mu jedynie oczekiwanie na sąd Boży, gdyż po chrzcie nie istniała już żadna możliwość czynienia pokuty ani odpuszczenia popełnionych grzechów. Podstawę biblijną dla takich poglądów stanowiłby tekst $\mathrm{Hbr} 6,4-8 ; 10,26-31 ; 12,16-17$. Jeśli takie przekonanie i praktyka istniałaby rzeczywiście w 1 . połowie II wieku, to wtedy Pasterz przekazując chrześcijanom nowe objawienie, które dopuszczalo pokutę pochrzcielną, byłby rzeczywiście reakcją na taki właśnie rygoryzm. Trzeba jednak dodać, iż pokuta pochrzcielna nie jest dla Hermasa praktyką stałą, lecz wyjątkową i jubileuszową, ponieważ związaną ściśle z bliską Paruzją. Druga natomiast teoria, określa Tauftheorie jako całkowicie falszywą. Według jej przedstawicieli przytoczone fragmenty Listu do Hebrajczyków nie dotyczą tak naprawdę drugiej pokuty, zaś na początku II wieku nie istnial żaden rygoryzm penitencjalny w nauczaniu bądź praktyce Kościoła ${ }^{49}$. Hermas natomiast nie naucza wcale o możliwości drugiej czy ostatniej pokuty pochrzcielnej, ale w ogóle o ostatniej szansie pokuty. Nie byłaby to jednak w żadnym wypadku jakaś nowa nauka pokutna, lecz Hermas opisałby aktualną w jego czasach praktykę pokutną. Nie byłaby to też żadna pokuta jubileuszowa, ale zwyczajna paenitentia secunda, podobna do tej, o której nauczał choćby później Tertulian, zaś fakt zbliżającej się Paruzji czynił by ją jedynie bardziej pilną ${ }^{50}$. Nie muszę dodawać, iż takie rozumienie nauki pokutnej Pasterza właściwie wyklucza jej boskie pochodzenie i jakąkolwiek nowość, a w konsekwencji Hermas nie bylby żadnym przekazicielem boskiego przesłania, lecz tylko autorem opisującym stan faktyczny. Cóż myśleć o tych teoriach? Opisują one rzeczywistość Kościoła II wieku czy też są tylko sztucznymi tworami badaczy wymyślonymi za biurkiem? Nie mający możliwości dokonania szczególowych analiz Pasterza przyjmuję tutaj za R. Jollym tzw. hipotezę pośrednią ${ }^{51}$. Słusznie podkreśla on

${ }^{48}$ Por. S. Czerwik, Zarys dziejów pokutnej praktyki Kosciota, w: A. Skowronek (red.), Sakrament pokuty, Katowice 1980, 127-175; A. Młotek, Pokuta i pojednanie w Kościele pierwotnym, „Colloquium Salutis” 17 (1985) 167-184; J. Janicki, Pokuta w nauczaniu i praktyce Kościola dwóch pierwszych wieków, „Folia Historica Cracoviensia” 3 (1996) 287-304.

${ }^{49}$ Por. np. A. D'Alès, La discipline pénitentielle d'après le Pasteur d'Hermas, RSR 2 (1911) 105-139, 240-265; tenże, L'Édit du Caliste, RSR 5 (1914) 52-113; B. Poschmann, Paenitentia secunda, Bonn 1940, 134-205; P. Galtier, Aux origines de la pénitence, Rome 1951, 132-143; K. Rahner, Die Busslehre im Hirten des Hermas, ZKT 4 (1955) 385-431.

${ }^{50}$ Por. Jolly, Introduction, SCh 53bis, 23-24.

51 Tamże. 
za innymi badaczami, iż z jednej strony byłoby błędem zakładać, tak jak to czyni Tauftheorie, że rygoryzm penitecjalny był swego rodzaju nauczaniem oficjalnym i powszechnym Kościoła w II wieku, to jednak z drugiej nie można również twierdzić, iż nie mial on wcale miejsca, gdyż potwierdzają to choćby liczne apokryfy (Ewangelia Egipcjan, Dzieje Piotra, Dzieje Pawta $i$ Tekli). Można oczywiście dyskutować o stopniu upowszechnienia się w Kościele pierwotnym rygoryzmu penitencjalnego, ale Pasterz staje się całkowicie niezrozumiały jeśli odrzucimy zupełnie perspektywę walki z nim autora dzieła. Potwierdzają to wyraźnie niektóre fragmenty pisma. W I Widzeniu sędziwa kobieta symbolizująca Kościól mówi:

„Nie przestawaj napominać twoich dzieci, gdyż wiem, że jeśli będą pokutować $z$ całego serca, zostaną zapisane razem ze świętymi w księgach życia"s2.

Kobieta-Kościól powierza tutaj Hermasowi przesłanie, że szczera pokuta prowadzi do przebaczenia, a określenie takie nie miałoby sensu, gdyby autor wcześniej wiedział o możliwości pokuty pochrzcielnej. Podobną wymowę posiada fragment II Widzenia:

„Kiedy oznajmisz im te słowa, które nasz Pan polecił tobie objawić, wtedy zostaną im odpuszczone wszystkie grzechy, jakie poprzednio popetnili, jak również wszystkich świętych, którzy zgrzeszyli aż do dnia tego, jeśli nawrócą się z całego serca i wyrwą niezdecydowanie z dusz swoich" ${ }^{\text {"53 }}$.

Potwierdza to wreszcie, paradoksalnie również X Przypowieść:

„A to, co mówię, nie odnosi się do tych dni nadchodzących, jakoby ktoś zaparłszy się teraz miał jeszcze możliwość pokuty. Jest bowiem rzeczą niemożliwą, aby został zbawiony ten, kto teraz ma zaprzeć się swego Pana. Dla tych jednak, którzy dawniej się zaparli, zdaje się istnieć możliwość pokuty" ${ }^{\text {"54 }}$.

Autor zawęża tutaj, to prawda, możliwość pokuty pochrzcielnej do obecnego wyjątkowego, jubileuszowego okresu, ale przypomnijmy, że jest to tylko zawężenie czasowe, a nie opis istniejącej sytuacji. Teksty te byłyby zupełnie niezrozumiałe, gdybyśmy przyjęli istnienie możliwości drugiej pokuty. Hermas jest więc powołany, by jako osoba świecka głosić innowacyjną naukę o możliwości pokuty pochrzcielnej $j^{55}$. Trudny dla nas pozostaje nadal do wyjaśnienia fakt owego jubileuszu pokutnego, gdyż nie bardzo wiadomo, co on oznaczał ani $\mathrm{z}$ czym się tak naprawdę wiązał. R. Jolly jest zdania, iż Hermas szukał kompromisu pomiędzy rygorystami, a zwolennikami pokuty pochrzcielnej w Rzy-

\footnotetext{
${ }^{52}$ Pastor. I Visio 3, 2, SCh 53bis, 84, thum. A. Świderkówna, BOK 10, 213.

53 Pastor. II Visio 6, 4, SCh 53bis, 90, BOK 10, 214.

54 Pastor. X Similitudo 103, 6, SCh 53bis, 344, BOK 10, 284.

55 Por. R. Jolly, Introduction, w: Le Pasteur, SCh 53bis, 26.
} 
mie w. II wieku. Stąd głosił możliwość drugiej pokuty, ale ograniczonej do obecnego czasu jubileuszowego, co byłoby swego rodzaju koncesją na rzecz rygorystów. Wyjaśnienie takie zakłada w sumie, że Hermas nie przekazuje żadnego przesłania "objawionego", lecz próbuje godzić dwie historycznie istniejące tendencje w Kościele rzymskim. Hipoteza ta nie jest jednak wcale taka oczywista i domaga się uzasadnienia. Czasowe bowiem ograniczenie możliwości drugiej pokuty nie jest wcale dla autora elementem zasadniczym, gdyz w innym miejscu podkreśla on, że możliwość pokuty istnieje dopóty, dopóki wieża-Kościół jest w budowie $(13,5)$. Nawet więcej, budowa owej wieży na pewien okres została przerwana, by wszystkim umożliwić czynienie pokuty $(91,2)$. Choć mamy tutaj do czynienia $\mathrm{z}$ symboliczną prezentacją Kościoła, to niewykluczone, iż autor miał na myśli okres ziemskiego istnienia Kościoła. A to oznaczałoby, że paenitentia secunda jest możliwa dopóki istnieje Kościół. Na zakończenie warto również dodać, iż novum przedstawione w Pasterzu w odniesieniu do pokuty pochrzcielnej stało się w Kościele pierwotnym rzeczywistością dynamiczną. Euzebiusz potwierdza, iż już ok. 170 r. Dionizy, biskup Koryntu, nie pisał nic o żadnych ograniczeniach czasowych w przypadku takiej pokuty i zalecał przyjmować do wspólnoty wszystkich, którzy pokutowali i „nawracają się z jakiegokolwiek upadku, czy to zwykłego przestępstwa, czy nawet $\mathrm{z}$ obłędu heretyckiego" 56 .

Hermas przedstawia się więc jako osoba świecka, która otrzymała misję głoszenia nauki „objawionej” o tym, że dla chrześcijanina istnieje możliwość pokuty po chrzcie. Czynił to wbrew tendencjom rygorystycznym w Kościele II wieku, które choć dosyć silne, to nie musiały być nauczaniem oficjalnym ani też powszechnym w Kościele. Niekoniecznie byłaby to więc korekta nauczania oficjalnego Kościoła, a jedynie przeciwstawienie się tendencjom w nim dominującym. Hermas czynił to jako świecki powołany do sprawowania charyzmatu prorockiego, który realizuje się między innymi poprzez właściwe zrozumienie kluczowych problemów swojej epoki i udzieleniu na nie odpowiedzi w świetle Ewangelii dzięki wewnętrznemu światłu Bożemu.

\section{APOLOGECI GRECCY II WIEKU}

W drugiej części naszych rozważań chcemy się zająć tematyką roli świeckich w tekstach chrześcijańskich Apologetów greckich II wieku. Ze względu na charakter interesujących nas pism konieczna jest również zmiana metody prezentacji naszej tematyki. Otóż, w pismach Apologetów greckich II wieku nie znajdziemy rozważanej w ogóle jako takiej kwestii roli świeckich w Kościele, gdyż autorzy tych pism koncentrowali się raczej na konfrontacji z otaczającym

${ }^{56}$ HE IV 23, 6, tłum. A Lisiecki, POK 3, 182. 
ich światem zewnętrznym, nie zaś na próbie opisu życia wspólnot chrześcijańskich. Dzieła te są jednak ciekawe zwłaszcza dlatego, że były pisane w większości właśnie przez ludzi świeckich, i doskonale pokazują rolę, jaką de facto odegrali oni w Kościele II wieku. Chodzi więc może nie tyle o analizę ich teoretycznych rozważań nad rolą świeckich w Kościele, gdyż tego w pismach nie znajdziemy, ile o podkreślenie rzeczywistej roli, jaką odegrali świeccy myśliciele i pisarze chrześcijańscy w tym okresie Kościoła. Chrześcijańscy apologeci greccy II wieku nie teoretyzowali więc nad rolą świeckich w Kościele, ale realizowali ją w praktyce, broniąc nowej wiary przed zagrożeniami zewnętrznymi i wewnętrznymi. Podczas gdy pośród pisarzy określanych mianem tzw. Ojców Apostolskich zasadnicza większość to duchowni ( $\mathrm{z}$ wyjątkiem być może autora Listu Pseudo-Barnaby i Pasterza), to wśród chrześcijańskich Apologetów greckich II wieku te proporcje prawie zupełnie się odwracają. Spośród bowiem znanych nam chrześcijańskich apologetów II wieku: Kwadratus, Arystydes z Aten, Aryston z Pelli, Justyn, Tacjan, Milcjades, Apolinary z Hierapolis, Atenagoras z Aten, Teofil z Antiochii, Meliton z Sardes, autor Listu do Diogneta i Hermiasz, jedynie Apolinary z Hierapolis, Teofil z Antiochii i Meliton z Sardes byli $z$ pewnością biskupami. Euzebiusz wspomina, iż po Publiuszu biskupem Koryntu został niejaki Kwadratus, lecz nie wiemy dokladnie, czy chodzi rzeczywiście o naszego apologetę czy też o kogoś zupełnie innego. Natomiast Arystydes, Aryston, Justyn, Tacjan, Milcjades, Atenagoras i prawdopodobnie również autor Listu do Diogneta byli osobami świeckimi. Widziane $z$ dzisiejszej perspektywy, ich nawrócenie się na chrześcijaństwo było rzeczywiście opatrznościowe. Większość bowiem z nich, przed przyłączeniem się do grona uczniów Chrystusa, była „zawodowymi” filozofami, lecz zniechęceni wobec dawnej religii, filozofii czy nawet sposobu życia ludzi swojej epoki, decydują się na przyłączenie do wyznawców nowej religii. Ich wykształcenie, wysoki status społeczny i zdolności literackie okazały się znakomitymi narzędziami, wlaśnie do obrony chrześcijaństwa przed różnego rodzaju zagrożeniami zewnętrznymi i wewnętrznymi. Tak więc jako osoby świeckie chrześcijańscy autorzy II wieku zaangażowali się głównie w trzy obszary działalności pisarskiej: obronę chrześcijan przed prześladowaniami ze strony Imperium Romanum i populistycznymi oskarżeniami, konfrontację z szeroko pojętą kulturą hellenistyczną oraz prezentację wiary chrześcijańskiej w kategoriach filozoficznych epoki jako postawę racjonalną oraz stworzenie podstaw teologii chrześcijańskiej, rozumianej jako próba refleksji rozumowej nad objawieniem. Ponieważ są to elementy, które stały się już przedmiotem wielu badań, dlatego też nie wydaje się rzeczą konieczną szczególowe ich tutaj przywoływanie ${ }^{57}$. Przed-

${ }^{57}$ Por. A. Puech, Les apologistes grecs du II siècle de notre ère, Paris 1912; J.R. Larin, Orientations mâtresses des apologistes chrétiens de 270 à 361, Roma 1954; R.M. Grant, Greek Apologist of the Second Century, Philadelphia 1988. 
stawię jedynie syntetycznie te najbardziej znane. Gatunek literacki, jaki stworzyli pisarze chrześcijańscy tej epoki, to zasadniczo apologia, tzn. obrona piórem religii chrześcijańskiej, adresowana bezpośrednio do władców, senatu rzymskiego lub wykształconych pogan. Strategia obrony zmieniała się w zalezności od tego, czego starano się bronić i jakie zarzuty odpierać. I tak, w odpowiedzi na populistyczne zarzuty o niemoralne postępowanie chrześcijan (kazirodztwo, kanibalizm), apologeci zazwyczaj opisują świętość i radykalizm moralny w postępowaniu chrześcijan, uznawany zresztą również przez wielu pogan oraz sam kult chrześcijański (Justyn, Tacjan, Teofil). Zdecydowanie trudniejsza była obrona przed prześladowaniami ze strony przedstawicieli władzy imperialnej. Ponieważ chrześcijaństwo było uznawane jako religio illicita, każdy, kto je wyznawał w obecności przedstawiciela władzy w terenie, był skazywany na śmierć. Apologeci II wieku odwoływali się wtedy do niewinności chrześcijan, podkreślając jednocześnie, że nie można ich skazywać tylko za sam fakt bycia chrześcijaninem, bez udowodnienia konkretnych przestępstw. Na niewiele się to jednak zdawało, gdyż dla władz sam fakt wyznawania nowej religii był już przestępstwem. Apologeci odwoływali się jednak w ten sposób również do pogan o dosyć wysokim statusie społecznym, których prawdopodobnie częściowo przekonywała ich argumentacja o tym, iż prawo rzymskie nie powinno skazywać na śmierć kogoś tylko dlatego, że wyznaje błędne przekonania. Strategia, trzeba przyznać, była bardzo mądra, gdyż jak wiemy, wśród pogan żyło wielu ludzi zachwyconych radykalizmem etyki chrześcijańskiej. Zwłaszcza jeśli pamiętamy, że wykształcony poganin II wieku chyba tak do końca w głębi swego serca nie wierzył w oficjalnie proponowany tradycyjny politeizm, traktując wyznawanie go jako swego rodzaju obowiązek społecznopaństwowy, samemu zaś szukając raczej kontaktu z religią filozofów, zwłaszcza platonizmem i stoicyzmem. To właśnie do ludzi bezpośrednio sprawujących władzę w cesarstwie oraz innych, wykształconych i wpływowych pogan byly skierowane teksty apologetyczne tego okresu. Apologeci II wieku nie bez przyczyny prezentowali więc chrześcijaństwo, jako taki właśnie rodzaj religii filozofów, możliwej do przyjęcia przez ludzi wykształconych. W opisie Boga i świata odwoływali się do znanych idei platońskich o istnieniu pośredników pomiędzy absolutnie transcendentnym Bogiem i światem, który dla chrześcijan był oczywiście identyfikowany z Logosem-Chrystusem. Zasadniczym jednak problemem była próba wyjaśnienia owym poganom niektórych kluczowych elementów wiary chrześcijańskiej, trudnych do pojęcia dla ich kulturowego universum, takich jak: tajemnica wcielenia, zbawczy charakter męki i śmierć na krzyżu Syna Bożego oraz zmartwychwstanie ciał. Stało się to więc motywem do pogłębienia tych prawd wiary i próbą racjonalnego ich wyjaśnienia dając początek teologii chrześcijańskiej. Nie trzeba dodawać, że teologia patrystyczna II wieku uwarunkowana była aktualnym kontekstem historycznym. Ograniczała więc swoją refleksję rozumową nad Objawieniem do kluczowych ele- 
mentów wiary chrześcijańskiej (nie wszystkich), a ich prezentacja nosi na sobie stygmat terminologii epoki i w dużej mierze jest uzależniona od adresatów.

Reasumując, w powyższych analizach udało się dojść do następujących wniosków, a mianowicie, aby właściwie zrozumieć użycie terminu „prorok” w Didache, konieczne jest rozróżnienie dwóch zakresów znaczeniowych. Raz termin ten jest używany w tekście jako kategoria ogólna, obejmująca wszystkich otwartych na działanie Ducha Bożego, innym natomiast razem oznacza konkretny charyzmat prorocki, rozumiany jako przepowiadanie przyszłości albo interpretacja teraźniejszości w świetle Ewangelii. Taka precyzacja pozwala nam określić rolę świeckich w Kościele rozumianym oczywiście jako wspólnota lokalna, która, zdaniem autora Didache, była potrójna: rozeznawać rzeczywisty charyzmat proroka wędrownego przychodzącego do wspólnoty, albo też pomiędzy rzeczywistym uczniem Pana a fałszywym chrześcijaninem, po drugie, dać utrzymanie prawdziwym prorokom i po trzecie, wybór biskupów i diakonów.

W Liście do Koryntian $(40,5)$ Klemensa Rzymskiego, pojawia się, jak wiemy, pierwszy raz w tekstach wczesnochrześcijańskich termin $\lambda \alpha$ ä̈ròs, który oznacza kogoś, kto nie spełnia posługi składania ofiar w imieniu wspólnoty. Ponadto, Klemens przypisuje świeckim ważną rolę w wyborze duchownych, choć jednocześnie zakreśla granice tych uprawnień w Kościele lokalnym świeccy nie mają prawa zdejmować $\mathrm{z}$ urzędu prezbiterów dobrze i godnie sprawujących swoją posługę.

Polikarp ze Smyrny koncentruje się raczej na opisie roli świeckich chrześcijan w świecie, którzy są powołani do dawania swoim życiem świadectwa Ewangelii i wierności wybranemu bądź aktualnemu stanowi ich życia: żony, wdowy, młodzież i dziewice.

Hermas natomiast, jako osoba świecka, otrzymuje misję głoszenia nauki „objawionej” o tym, że dla chrześcijanina istnieje możliwość pokuty po chrzcie. Byłby więc $w$ jakimś sensie prekursorem tych wszystkich ludzi świeckich w historii Kościoła, którzy otrzymywali misję głoszenia światu „objawień,, wspomagających lepsze rozumienie objawienia publicznego.

Apologeci greccy II wieku natomiast, choć nie pisali nic na temat roli świeckich w Kościele, to sami, będąc w przeważającej większości ludźmi świeckimi, zaangażowali się w obronę chrześcijan przed fałszywymi oskarżeniami i prześladowaniami, polemikę $\mathrm{z}$ politeizmem oraz prezentację wiary chrześcijańskiej w kategoriach filozoficznych epoki. 


\title{
IL RUOLO DEI LAICI NELLE OPERE DEI PADRI APOSTOLICI E DEGLI APOLOGISTI GRECI
}

\author{
(Riassunto)
}

Per descrivere il ruolo dei laici nella Chiesa antica negli scritti dei Padri Apostolici ci siamo concentrati su Didache, L'Epistola ai Corinti di Clemente Romano, 1 e 2 Lettera ai Filippesi di Policarpo di Smyrne e Pastore di Erma. Abbiamo quindi sottolineato che per capire bene i diversi carismi nella Chiesa primitiva descritti nella Dottrina dei Dodici Apostoli bisogna distinguere tra l'uso del termine „profeta" come una cattegoria generica che abbraccia tutti coloro che sono aperti all'azione dello Spirito Santo e quello più specifico come carisma profetico data alla comunità dei credenti per interpretare meglio il tempo presente alla luce del Vangelo. Un'altra premessa merita ancora di essere messa in rilievo, e cioè, che secondo la Didache eventuale ruolo dei laci riguarda la comunitą ecclesiale locale e non la Chiesa universale. Detto questo il ruolo dei laci in quest'opera sarebbe triplice: discernere tra un profeta itinerante vero da quello falso, poì, sostenere materialmente i veri profeti (qui inizia la famosa decima) e infine partecipare attivamente all'elezione dei vescovi e diaconi.

Epistola ai Corinti $(40,5)$ per la prima volta appare il termine גaïxòs che significa qualcuno che non offre i sacrifici di culto al nome della comunità. Oltre questo, Clemente attribuisce ai laici il compito di eleggere i presbiteri, che però quando svolgono il loro servizio in maniera degna non possono essere dimessi da nessun laico.

Policarpo di Smyrne si concentra sulla descrizione dei compiti dei laici che vivono nel mondo, cioè mogli, vedove, giovani e vergini, chiamati anche essi a dare la testimonianza al Vangelo nella vita quotidiana.

Erma invece riceve la missione di annuziare il messaggio „rivelato" a tutti i cristiani che esiste una paenitentia secunda dopo il battesimo. Sarebbe quindi in qualche modo il precursore di tutti quei laici lungo la storia della Chiesa che hanno ricevuto le "rivelazioni” private come un aiuto per comprendere meglio la rivelazione pubblica in un determinato contesto storico.

Per quanto riguarda invece gli Apologisti greci, nei loro testo non troveremo alcunchè sul ruolo dei laci nella Chiesa del II secolo. Loro stessi però, nella stragrande maggioranza laici, hanno svolto il ruolo fondamentale nella difesa del cristianesimo dalle false calunnie popolari e dalla persecuzione imperiale, si sono impegnati nella polemica con il politeismo pagano e anche sforzati di presentare la fede cristiana nelle cattegorie filosofiche dell'epoca. 